\title{
The Spiritual Crisis of Modernity and Tu Wei-Ming'S Concept of Self-Cultivation
}

\author{
Valery Kiselev \\ Peoples' Friendship University of Russia \\ 6, Miklukho-Maklaya St, Moscow, Russia 117198 \\ valery.kiselev@gmail.com
}

\author{
Varvara Chernykh \\ Peoples' Friendship University of Russia \\ 6, Miklukho-Maklaya St, Moscow, Russia 117198 \\ onufrieva.varvara@yandex.ru
}

\begin{abstract}
This article dwells upon the spiritual problems in modern Chinese society. The term 'spirituality' covers not only the value of ethical categories on the traditional China, but also the humanism as the tandem of both religious and ethical components towards human beings. The basic categories of Confucian ethics, 'reinterpreted' through the tradition of analytical philosophy, have acquired a new character - Tu Wei-ming gave them the new understanding through the concept of Self-Cultivation. The process of cultivating occurs for the sake of the human involved into that and is not caused by any external factors.
\end{abstract}

Keywords-contemporary Confucianism; Russian religious philosophy; spiritual crisis in China; Eastern humanism; problems of human nature; concept of Self-cultivation; ritual propriety (li); rectification of names (zheng ming)

\section{THE SPIRITUAL CRISIS IN CHINA}

At present, China is experiencing the same spiritual problems that the whole world is. However, the problems of spirituality in China are specific, due to the huge philosophical heritage of the country and century-old complicated relations with the Western civilization that were built during the close economic and cultural interaction of the civilizations.

On the one hand, the influence of philosophical concepts on the life of the state, society and individuals in common was traditionally strong in China. At the same time, the Chinese thought has been traditionally oriented towards human, to one's self-realization, which resulted in the formation of the ideal person concept. Chinese thinkers attempted to reveal how to be a person, what he represents in his wholeness and, thus, what a society should there be for a human being to be able to fully realize his own potential.

Despite the fact that at the end of the $20^{\text {th }}$ and in the beginning of the $21^{\text {st }}$ century China has become one of the world's strongest powers, has created powerful economy, and actively develops modern technologies, pays much attention to social issues, there are a lot of people pointing to the deterioration of the spiritual atmosphere in Chinese society. Some of them talk about National spiritual crisis, manifested in the rapidly lowering importance of traditional values (for example, respect for governance, parents, and elders) and link this crisis to the fact that Western values e.g. the competition, the power of money, and consumerism were actively absorbed during construction of modern economy in China.

The Marxists, as well as representatives of the contemporary Confucianism are searching ways out of the crisis. Each of them attempts to, somehow, synthesize the traditional Chinese moral and ethical teachings and different philosophical conceptions of Western thinkers. In 2001, Jiang Zemin put forward the thesis "rule by virtue". According to this thesis, the new moral order proposes to establish a more harmonious relationship between a man and nature, which in essence is a transposition of traditional Confucian values intuitively understandable to the Chinese, but expressed in a modern form and applicable in modern conditions. One of the examples is the concept of Tu Weiming, a representative of modern Confucianism, who believes that the basis of Confucianism is the principle of "being Human", that human being is the only bearer of morality in the universe.

Human was not created to serve society. He is the goal himself, and should implement his own "being". Without this, it is impossible to achieve harmony in society and in the state at all. Without Self-Cultivation, it is impossible to achieve harmony in society. Anthropocentricity has always been one of the most important characteristics of Chinese thought throughout history, which was reflected as a consideration of the person through the prism of his interactions with the society and identification his essential nature. For Confucius - a human is somewhat an empty sheet that is being formed in the process of education; Mencius believed that a man is kind by nature, and Xun Kuang believed that a man is evil; Dong Zhongshu and Han Yu singled out three categories of human nature. Confucians do not deny the presence or the absence of the transcendent at all. Tu Wei-ming uses the term "inclusive humanism" in case to divine the concept of the Confucian humanism from the different forms of secular versions of it [1]. Interesting fact is that the process of selfrealization entails not only being the part of the society but also building a "dialogical response to the transcendent" [2]. In that case, the question is whether Confucianism as the humanism can be presented as not only the ethics but also religion. It is a clear fact that Confucianism is not an institutional religion, however there are also ethical, aesthetic and religious components that cannot be separated from one another. The latter is closely linked to the understanding the 
nature of a human being and how he implements the process of his perception of the world's historical events. Russian religious philosopher Berdyaev N.A. claims that the history is the history of the human being, determinated by his retrospective self-reflection, his self-recognition. At the same time, all aspects must be accompanied by the aspiration to the God through mind actions. "All historical eras, from the very beginning to the current events - all of them are my historical destiny; all is mine, my act." [3]

\section{The CONCEPT OF SELF-CUltivation (XIUSHEN, 修 身)}

The basic categories of Confucian ethics, "reinterpreted" through the tradition of analytical philosophy, have acquired a new character - Tu Wei-ming gave them the new understanding through the concept of Self-Cultivation. According to this idea, the process of cultivating occurs for the sake of the human involved into that; this action, regarded as a genuine blessing, is not caused by any external factors (e.g. society, family etc.).

However, it cannot be called only as a self-centered action. The individuality, the autonomy of the individual and human dignity can only be identified by Self-Cultivation. It includes the dualistic perception of the individual: on the one hand, an individual self "nurture" in his particular manifestation, taking into account all the set of qualities that distinguish him from the entire society (gender, ethnical identity, age, religious beliefs, level of education or what language he speaks and what social roles it manifests himself). On the other hand, man goes beyond his own ego, and then opens himself up to the society. Living in the world "here-and-now", he goes beyond the self to perceive the world in its totality; and vice versa - if he wants to be in the position above, therefore he must have some kind of center, not to lose his own identity (e.g. mother tongue, ancestral home, class, and religious faith) [4]. "The human way is therefore neither theocentric nor anthropocentric. Rather, it points to the mutuality of Heaven and man. By insisting upon a continuous interaction between them, the human way necessitates a transcend anchorage for the existence of man and an immanent confirmation for the course of Heaven." [5].

Human knowledge, especially philosophical one, depends on the spiritual condition of the people he live with, from the volume of their consciousness to the forms of unity and communication processes, which play a huge role in that. Philosophical knowledge is personal, and the more personal it becomes, the more it becomes substantial to human being. Nevertheless, the personal character of knowledge does not mean the isolation of the individual at all. The human learns something new in the community and interacts with the entire world and people, and attaches himself to international experience and global thoughts. The process of cognition is both personally and socially. Moreover, the degree of the spiritual community of people play a huge role here. It all goes back to that basic truth that knowledge is anthropological, but this does not mean relativity. The question is whether the human beings are at all viable species in the modern world and how the Self-Cultivation may help to overcome all the problems raised in the modern world [6].

\section{CONFUCIAN HUMANISM}

As it was mentioned, the main aim and result of the process of Self-Cultivation is the harmonic unity between the Heaven (tian, 天) and Man. The human desire is not only to embody, in the truest sense of the word, the fullness of "man created in the image and likeness of God", but also to build harmonious relations "Man-World" and "Man-Society" [7]. Therefore, that process cannot be realized without the community: "One becomes fully human within a community. The Confucians believe that normally it is desirable to establish fruitful communication with the transcendent through communal participation." [8]. It is the basic pattern to build social relations in different spheres of life. Thus to help to succeed in that process there are different virtues, such as the ritual propriety. To be one of the fundamental Confucian virtues gives the value-oriented adjustment in the way "to be a self-made man". It is the way to accept all the established social roles of a person, the way to be selfdisciplined. However, another problem arises in that way; how to find the balance between the role to be the "civilian of the entire world" and the "civilian of your own motherland".

Self-Cultivation is also a process of transformation that relates to all levels of the society (from the family to the entire universe) e.g. the parental love to their children. They share their love to children and that entails the process of bringing up the love to the entire world. Moreover, it is the mutual process. Parents learn to care for their own children and gradually release them from themselves, thereby cultivating the responsibility for their own actions in them [9]. For Tu Wei-ming, the respect for parents, in turn, is expressed not when they are no longer able to take care of themselves, but when they have the desire to become independent, not in economic but in spiritual and physical terms, that give themselves in the truest sense of "freedom" from further care. To be a good person, you must learn how to love, and that means to follow "the path of humanism and the Tian": more often, children receiving comprehensive care and love of parents cannot take this kind of subtle matter seriously because of their own adolescent immaturity [10].

However, if they accept and understand that idea, they will start to follow the path to the humaneness (ren, 仁). It is not only a personal-to-personal virtue, in a metaphysical way, but also a moral category (at the expense of the aspirations of Boston scientists to build a comprehensive and universal ethics) [11]. For example, the concept of considerate behavior manifestates the illustration of the concept of rectification of names (zheng ming, 正名). In connection with a commitment to cultural diversity in a globalizing world, there arose the need to create a specific social habit aimed to build mutual respect and tolerance towards other cultures and religions. Being a part of the society human being enriches his own horizons in cultivating virtues, and, therefore, participating in the social activity, enriches the community from the inside [12]. 


\section{CONCLUSION}

Tu Wei-ming is Harvard-Yenching professor of Chinese history and one of the leader of the Boston Confucianism. Boston Confucianism is a kind of microcosm, which implies philosophical cultural project. The attention of the Boston scientists is also drawn to the main development of the objectives of the entire Confucian thought in the modern world. Discussions are usually dwells upon the ways to create the number of possible strategies or ways to develop the more global movement, and the emphasis on the differences between the views of scientists on these paths much varies from the views of the general public.

The concept of Tu Wei-ming gives the opportunity to restore traditional values to a modern, qualitatively new stage, in contrast to the spiritless and economic values of the modern Western world. These values led to the modern spiritual crisis. The Tu Wei-ming's concept of the SelfCultivation is an attempt to find the universal output from the spiritual crisis, is suitable for the Chinese (Confucian) world, but for humanity as a whole. Thus, the concept of Tu Weiming is largely academic. In China, the philosopher does not have sufficient authority to make his ideas become the basis to the national policy in the area of spiritual renewal.

\section{REFERENCES}

[1] Tu Wei-ming, Centrality and commonality: an essay on Confucian religiousness. Revised and Enlarged Edition of Centrality and Commonality: An Essay on Chung-yung. NY.: SUNY Press, 1989, p.97.

[2] Ibid.

[3] N. A. Berdyaev, The crisis of Art. Moscow: SP Interprint, 1990 [reprint], pp.23-24.

[4] Tu Wei-ming, Cultural China: The Periphery as the Canter // Daedalus, 1991, Vol. 120, No. 3, pp. 7-9.

[5] Tu Wei-ming, Centrality and Commonality: An Essay on Confucian Religiousness, p. 9.

[6] Tu Wei-ming, Cultural China: The Periphery as the Center, p. 27.

[7] N. A. Berdyaev, The crisis of art, p.57.

[8] Tu Wei-ming, Centrality and commonality: An Essay on Confucian Religiousness. P. 97.

[9] Tu Wei-ming, Confucian thought: selfhood as creative transformation. Neville R.C. (ed.), Albany, State University of New York Press, 1985, p. 102.

[10] Ibid. p. 103.

[11] R. C. Neville, Boston Confucianism: portable tradition in the latemodern world, Albany, State University of New York Press, 2000, pp. 96-102.

[12] Tu Wei-ming, Daisaku Ikeda, New horizons in Eastern Humanism: Buddhism, Confucianism and the Quest of Global Peace, London, I.B. Tauris \& Co. Ltd., 2011, pp. 14-17. 